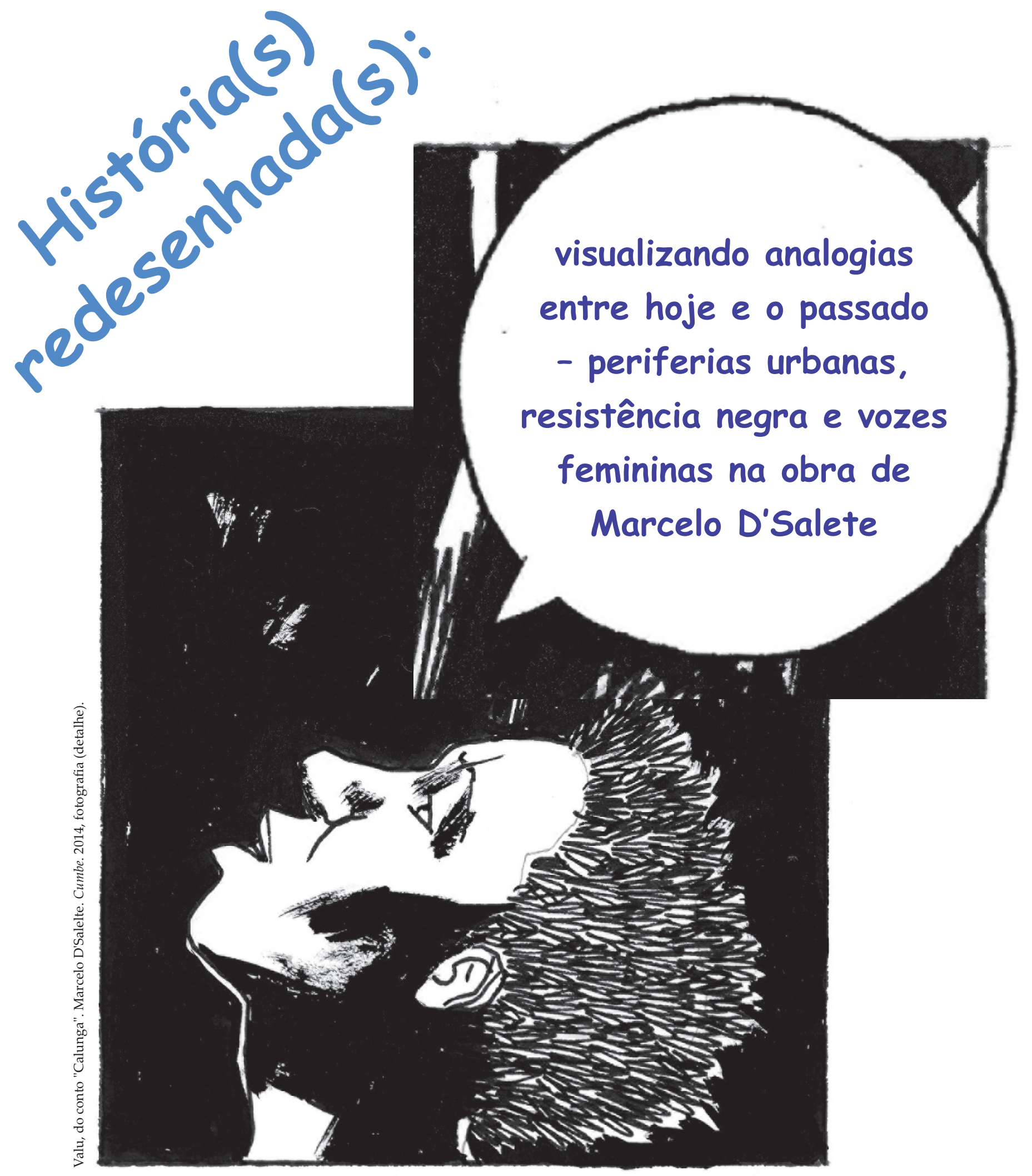

Jasmin Wrobel

Doutora em Estudos Latino-Americanos pela Freie Universität Berlin (FUBerlin). Organizadora do livro Roteiros de palavras, sons, imagens: os diálogos transcriativos de Haroldo de Campos. Frankfurt am Main: TFM, 2018. jasmin.wrobel@fu-berlin.de 


\section{História(s) redesenhada(s): visualizando analogias entre hoje e o passado - periferias urbanas, resistência negra e vozes femininas na obra de Marcelo D'Salete}

Re-drawn histories: visualizing analogies between the present and the past - urban peripheries, black resistance and female voices in the work of Marcelo D'Salete

\section{Jasmin Wrobel}

\section{RESUMO}

Em suas HQs, o artista e professor de artes visuais paulistano Marcelo D'Salete tematiza a história afro-brasileira e as condições de vida de jovens afro-brasileiros no presente, traçando analogias entre hoje e o passado com seus livros Noite luz (2008), Encruzilhada (2011), Cumbe (2014) e Angola Janga (2017). Neste artigo, pretende-se mostrar como o autor consegue (re) desenhar um retrato entre ficção e realidade, tanto da periferia urbana como da história de Palmares, criando, assim, uma "continuidade invertida" entre suas primeiras obras, que documentam a vida dos seus protagonistas nas ruas de São Paulo, e as duas mais recentes, em que identifica a raiz da desigualdade social hoje na história mal digerida da escravatura no Brasil. Em um terceiro passo, ainda se tematizará o papel das vozes femininas que também não são esquecidas por D'Salete.

palavras-chave: Marcelo D'Salete; periferia urbana; Palmares.

\begin{abstract}
In his graphic novels, São Paulo artist and Visual Arts professor Marcelo D'Salete illustrates decisive moments of Afro-Brazilian history and the life conditions of young Afro-Brazilians in the present, tracing analogies between now and then in his books Noite luz (2008), Encruzilhada (2011), Cumbe (2014) and Angola Janga (2017). In this contribution, I intend to show how D'Salete - on the threshold between fiction and reality - (re)draws a portrait of the urban periphery, on the one hand, and the history of Palmares, on the other hand, creating a type of "inverted continuity" between his first two works focused on São Paulo street life and his more recent graphic narratives in which he identifies the root for today's social inequality in the poorly digested history of slavery in Brazil. In a third step, I am going to discuss the role and potential of the voice of women who are not being forgotten in D'Salete's work.

KEYWORDS: Marcelo D'Salete; urban periphery; Palmares.
\end{abstract}

${ }^{1}$ FERRÉZ. Terrorismo literário. In: FERRÉZ (org.). Literatura marginal: talentos de escrita periférica. Rio de Janeiro: Agir, 2005, p. 9 .

${ }^{2}$ Uma das primeiras obras gráficas que assumiu a memória traumática como tema foi, evidentemente, Maus, de Art Spiegelman (1986/1991). Na América do Sul, tais relações podem ser pensadas com o surgimento das ditaduras na segunda metade do século $\mathrm{XX}$ quando temos, por exemplo, o "desaparecimento" e o assassinato do quadrinista argentino Héctor Germán Oesterheld em 1977.

A regra é só uma, mostrar as caras. Não somos o retrato; pelo contrário, mudamos o foco e tiramos nós mesmos a nossa foto. ${ }^{1}$

Nos últimos anos, podemos observar a tendência em retrabalhar experiências e acontecimentos históricos traumáticos sob a forma de histórias em quadrinhos (HQs) que, como meio, permite um enfoque novo e também a introdução de novas perspectivas sobre temas sensíveis. ${ }^{2} \mathrm{~A}$ arte dos quadrinhos possibilita releituras de temas complexos, considerando também que as formas de representação podem variar entre imagens meramente simbólicas e outras quase brutais a partir de seu conteúdo explícito. $\mathrm{Na}$
\end{abstract}


América Latina, essa tendência se estende, por exemplo, à história colonial, à história da escravidão, às ditaduras no século XX, mas também a situações de discriminação e abuso contemporâneos. No contexto da abordagem de discursos de memória na arte sequencial na América Latina, pode-se citar, por exemplo, as recentes publicações de Catalá Carrasco, Drinot e Scorer e de Carrillo Zeiter e Müller. ${ }^{3}$

Nos últimos anos, o artista, ilustrador e professor paulistano Marcelo D'Salete tem recebido muita atenção internacional por suas obras, culminando na condecoração com o Eisner Award, na categoria melhor edição americana de material internacional por $\mathrm{Cumbe}^{4}$, bem como o Troféu HQ Mix 2018 nas categorias de desenhista nacional, roteirista nacional, destaque internacional e edição especial nacional por seu trabalho Angola Janga. ${ }^{5}$ Enquanto em Noite luz $z^{6}$, Encruzilhada e Risco ${ }^{7}$, o autor problematiza as condições de vida contemporâneas de jovens afrodescendentes nas periferias de São Paulo, em Cumbe e Angola Janga D'Salete recupera e (re) desenha a história do Quilombo dos Palmares, não raro contada, até hoje, sob uma perspectiva branca, valendo-se de uma extensa pesquisa acadêmica e iconográfica de mais de dez anos sobre a temática.

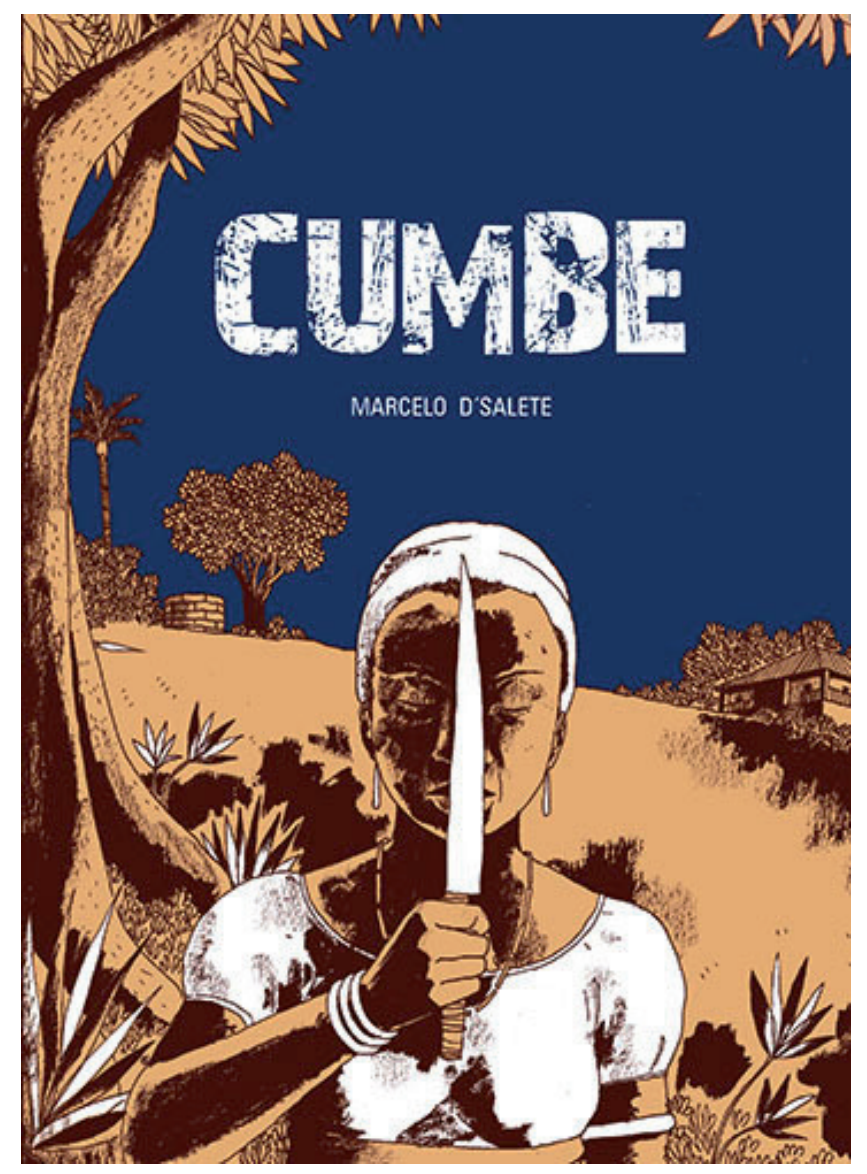

Figura 1. Capa do livro Cumbe. ${ }^{8}$

A opção por narrar a saga de Palmares por episódios possibilita a D'Salete enunciar tal processo histórico desde ângulos diferentes, incluindo não somente a perspectiva de figuras como Zumbi dos Palmares e outros atores da resistência negra, mas também a perspectiva associada a figuras femininas. Neste sentido, pretendo analisar as estratégias visuais aplicadas

\begin{abstract}
${ }^{3}$ Ver CATALÁ CARRASCO, Jorge e DRINOT, Paulo e SCORER, James (orgs.). Comics and memory in Latin America. Pittsburgh: University of Pittsburgh Press, 2017, e CARRILLO ZEITER, Katja e MÜLLER, Christoph (orgs.). Historias e historietas: representaciones de la historia en el cómic latino-americano actual. Frankfurt am Main: Vervuert, 2018.
\end{abstract}

${ }^{4}$ D'SALETE, Marcelo. Cumbe. São Paulo: Veneta, 2014.

${ }^{5}$ Idem, Angola Janga: uma história de Palmares. São Paulo: Veneta, 2017.

${ }^{6}$ Idem, Noite luz. São Paulo: Via Lettera, 2008.

${ }^{7}$ Encruzilhada e Risco foram originalmente lançadas em $2011 \mathrm{e}$ 2014, respectivamente. Contam com reedição recente, num único volume. Ver D'SALETE, Marcelo. Encruzilhada. 2. ed. São Paulo: Veneta, 2016.

${ }^{8}$ Idem, Cumbe. Wien: Bahoe Books, 2017 (capa da versão alemã). 
${ }^{9}$ Ver HAPKE, Ingrid. Konfliktfelder: Die 'literatura marginal/periférica' und ihr 'literarischer Terrorismus'. In: KLENGEL, Susanne (org.). Novas vozes: zur brasilianischen Literatur im 21. Jahrhundert. Frankfurt am Main/Madrid: Vervuert/Iberoamericana, 2013, p. 109.

${ }^{10}$ Ver RINKE, Stefan e SCHULZE, Frederik. Kleine Geschichte Brasiliens. München: C.H. Beck, 2013, p. 110 e 111.

${ }^{11}$ Sobre a linguagem dos quadrinhos, ver EISNER, Will. Comics and sequential art. Tamarac: Poorhouse Press, 2000, McCLOUD, Scott. Understanding comics: the invisible art. New York: HarperCollins, 1993, e COHN, Neil. The visual language of comics: introduction to the structure and cognition of sequential images. London: Bloomsbury, 2013. por D'Salete para representar o ponto de vista dos subalternos e discutir em que medida o autor consegue contar as histórias dos seus protagonistas assumindo-os enquanto efetivos agentes da História - ou seja, sem simplesmente vitimizá-los, mas sim tematizando suas resistências e suas personalidades complexas. Pretendo mostrar ainda em que medida tais obras dedicadas a reescrever episódios da história da escravidão no Brasil se relacionam, quase como numa continuidade invertida, com as primeiras obras que tematizam a situação problemática dos jovens afro-brasileiros no espaço urbano na atualidade.

\section{Algumas reflexões sobre $H Q$, marginalidade e periferia}

A presença e a visibilidade afro-brasileiras nos campos literário e artístico no Brasil ainda deixam a desejar, com poucas exceções. Devido a um etnocentrismo literário que reflete as desigualdades sociais, os protagonistas negros na literatura brasileira são escassos e, quando existem, muitas vezes tratam-se de figuras estereotipadas e pouco complexas do ponto de vista literário. Com a publicação do best-seller Cidade de Deus (1997), de Paulo Lins, e, especialmente, com sua adaptação cinematográfica dirigida por Fernando Meirelles e codirigida por Kátia Lund [2002], as periferias urbanas do Brasil recente mereceram atenção internacional inédita. Ao mesmo tempo, vozes como as do poeta, rapper e ativista paulistano Ferréz (Reginaldo Ferreira da Silva), um dos fundadores da "literatura marginal" que se desenvolveu nas periferias de São Paulo a partir dos últimos anos da década de 1990, começaram a ser ouvidas com maior atenção. As autoras e os autores identificados com esse movimento, sendo eles mesmos da periferia, problematizam temáticas como a pobreza, a discriminação ou a violência cotidiana sofrida pelos moradores por diferentes agentes - traficantes ou policiais, por exemplo. ${ }^{9}$ Tais vozes recusam certa interpretação historiográfica tradicional do Brasil, identificando as raízes dos problemas e conflitos contemporâneos na mal digerida história da escravidão do país. $\mathrm{O}$ Império do Brasil foi o último país independente no continente americano a abolir a escravidão. A integração dos "libertos" na sociedade brasileira como participantes ativos se deu sob difíceis condições e muitas vezes os antigos escravos voltaram para as plantações para trabalhar sob péssimas condições; outros tentaram achar trabalho nas cidades, onde tiveram que competir com trabalhadores emigrantes. ${ }^{10}$ A situação marginal e precária dos afro-brasileiros permanece como uma condição histórica, refletida até hoje, em certa medida, no Brasil contemporâneo.

Por muito tempo, as HQs foram vistas como um gênero marginalizado, uma forma de subliteratura. A partir dos underground comix dos anos 1960 e 1970, em especial, elas têm certa tradição de destacar protagonistas que se encontram à margem da sociedade por diferentes razões, o que as tornam um meio privilegiado tanto para contar a vida nas periferias urbanas contemporâneas como para (re)desenhar a história dos oprimidos no Brasil. A linguagem dos quadrinhos ${ }^{11}$ permite a visualização explícita de estruturas hierárquicas, da desigualdade social e das discriminações sofridas. Através de estratégias narrativas gráficas e das mudanças de perspectiva visuais (high angle e low angle), torna-se possível mostrar os desequilíbrios nas relações hierárquicas na sociedade; ao mesmo tempo, os mesmos instrumentos estilísticos permitem expressar a voz dos subalternos, suas rebeliões e a resistência cotidiana contra os opressores, mostrando, 
por exemplo, close-ups dos rostos decididos dos protagonistas, olhares que representam consternação, medo ou também relutância e aversão. No gênero das graphic novels, as histórias dos subalternos são incorporadas num meio que, desde pelo menos a publicação de Maus, de Art Spiegelman, é levado "a sério" e permite narrar visualmente temáticas complexas e desafiadoras. Por integrar uma linguagem historicamente associada ao público infanto-juvenil a um cuidadoso formato de edição mais próximo do livro e, portanto, mais próximo de um universo adulto e letrado, as graphic novels despertam o interesse de um público mais amplo.

Não surpreende, portanto, o fato de que, nos últimos anos, tenham sido publicadas várias obras que tematizam graficamente as periferias no Brasil. Além dos livros de Marcelo D'Salete que serão discutidos mais adiante, podemos mencionar as obras Jubiabá (2009), de Spacca - adaptação do romance de Jorge Amado -, O morro da favela (2011), de André Diniz - que conta a história do fotógrafo Maurício Hora no Morro da Providência - e Carolina (2016), de Sirlene Barbosa e João Pinheiro, uma espécie de biografia em quadrinhos da escritora Carolina Maria de Jesus a partir de suas obras Quarto de despejo: diário de uma favelada (1960) e o Diário de Bitita (1986, póstuma). Relacionada a esta última publicação é preciso mencionar também o fato de que as HQ se transformaram num espaço onde, mais recentemente, negociam-se discursos feministas. Enquanto autoras e protagonistas, as mulheres descobriram e conquistaram o espaço das HQs para elas, dando um novo rosto à "nona arte", ao buscarem uma abordagem não sexualizada e estereotipada - perspectiva que marca a história das HQ - em seus trabalhos.

\section{Um retrato diferente: a periferia urbana na obra de Marcelo D'Salete}

Marcelo D'Salete nasceu e vive em São Paulo, palco também de muitas das suas HQs. Ele estudou Desenho Gráfico e Belas Artes na Universidade de São Paulo (USP) e concluiu um mestrado em História de Arte pela mesma universidade. Atualmente, D'Salete trabalha como ilustrador e ensina Artes Visuais na Escola de Aplicação da USP. O autor publicou os primeiros contos gráficos nas revistas nacionais Front, Graffiti, Quadreca, +Soma e Contos Bizarros, na revista eslovena Stripburger e na revista argentina Suda Mery K!.

Os primeiros livros, Noite luz e Encruzilhada, além do conto gráfico "Risco", integrado à segunda edição de Encruzilhada, de 2016, relacionamse em função da escolha em comum pelo cenário principal - São Paulo e suas periferias - e pelas condições sociais dos seus protagonistas. Aqui, o autor revela e documenta os lados problemáticos da cultura urbana que afetam as vidas das suas figuras: a desigualdade social, a violência urbana e institucionalizada, a discriminação e o racismo.

Noite luz é composto de seis contos gráficos: "Noite luz", "Entre rosas e estrelas", “Graffiti”, “Buldog”, “O patuá de Dadá” e “Sexta”. Todos eles se integram não somente pelo cenário - um bairro degradado de uma cidade brasileira que, mesmo não apresentada nominalmente, claramente remete a São Paulo - mas também pelo bar que empresta seu nome ao título da primeira história e do volume, "Noite luz". O bar aparece em todos os contos, ora tendo uma função chave para o argumento, ora servindo apenas como um dos cenários do bairro visitado pelas figuras. O nome do local 
${ }^{12}$ Ver D'SALETE, Marcelo. Noite luz, op. cit., p. 9, 13-15, 18 e 21.

${ }^{13}$ Ver idem, ibidem, p. 52 e 53, 56 e 57.

${ }^{14}$ Ver idem, ibidem, p. 52, 54 e $55,58$.

${ }^{15}$ Ver idem, ibidem, p. 37 e 38, p. 42 e $43,47$.

${ }^{16}$ Ver idem, ibidem, p. 78-80.

${ }^{17}$ Ver idem, ibidem, p. 46.

${ }^{18}$ Ver idem, ibidem, p. 50.

${ }^{19}$ Para uma análise detalhada dos contos gráficos de Encruzilhada, ver WROBEL, Jasmin. Narrating other perspectives, re-drawing history: the protagonization of Afro-Brazilians in the work of graphic novelist Marcelo d'Salete. In: CARVALHO, Vinicius Mariano de e GAVIOLI, Nicola (org.). Literature and ethics in contemporary Brazil. New York: Routledge, 2016. indica também o estilo de desenho de Marcelo D'Salete, que segue certa tradição chiaroscura nas suas HQs, trabalhando unicamente com preto e branco e suas gradações, além de simbolizar as situações vivenciadas por seus visitantes, os protagonistas de Noite luz: o argumento principal nos contos quase sempre se desenvolve de noite, na escuridão. Muitas vezes, as personagens ficam na sombra, sem serem reconhecíveis, como o perseguidor da protagonista Márcia, do conto que empresta seu título à obra, que usa um boné que deixa seu rosto completamente sombreado, recurso que aumenta a sensação de ameaça provocada pelo personagem. ${ }^{12}$ Outras vezes, usam capacetes, como no conto "Buldog", deixando suas identidades às escuras num primeiro momento. ${ }^{13}$ Tal jogo de identidades e disfarces é intensificado pelo estilo cinematográfico de narrar de Marcelo D'Salete: o autor varia os ângulos nas vinhetas constantemente, fazendo uso de close-ups e perspectivas high angle e low angle, o que lhe permite mostrar detalhes que normalmente passariam despercebidas pelo leitor e ofuscar outros momentos no argumento que só ficam compreensíveis no final do conto.

Outro elemento que faz parte desse jogo são os símbolos relacionados a alguns dos personagens como, por exemplo, a tatuagem de buldogue, no caso do segurança no conto homônimo ${ }^{14}$, e que já antecipa, em certo grau, o momento de violência brutal nessa história. Em "Graffiti", por outro lado, a protagonista Benê entrega ao namorado Dito um desenho de Iansã, a senhora dos ventos e das tempestades da mitologia iorubá e que também simboliza o entardecer. Dito cria um grafite baseado nesse desenho - que se transforma no leitmotiv do conto - para reconquistá-la. ${ }^{15}$ De fato, todos os elementos visuais que exercem tal função simbólica em Noite luz aparecem como símbolo isolado na primeira página de cada conto. Também há momentos de "luz" nos episódios narrados por Marcelo D'Salete, mas quase nunca terminam com um "final feliz", visto que a escuridão e a noite dominam o destino dos protagonistas. Um elemento de "luz" e esperança como contraponto à "noite" é introduzido com o personagem do catador mudo Aldair, que aparece nos contos "O patuá de Dadá" e "Graffiti". No primeiro, ele salva a vida do pequeno Dadá/Antônio ${ }^{16}$; no segundo, ele ajuda com a reunião de um casal. ${ }^{17}$ É importante, nesse contexto, o fato dele ser catador, de trabalhar com papel e, mais ainda, de colecionar fotografias. Às vezes elas se encontram sob a forma de fragmentos, como no caso de "Graffiti", onde, ao final do conto, o catador não só consegue reaproximar os protagonistas Benê e Dito, mas também junta os pedaços da fotografia do casal que Benê tinha rasgado ao começo do conto.

Ele alfineta a fotografia no final do conto numa parede onde já se encontram inúmeras fotos de outras pessoas. ${ }^{18} \mathrm{O}$ personagem do catador Aldair pode ser concebido, em certo sentido, como uma espécie de alter ego do próprio autor: ele junta todos esses momentos registrados dos moradores do bairro compondo, assim, suas histórias, num mosaico urbano e silencioso. $O$ fato dele ser mudo combina também com o estilo de narração do próprio Marcelo D'Salete, que deixa as palavras a seus protagonistas e prescinde de narração externa. Ao mesmo tempo, a "falta de voz" de Aldair, catador e morador de rua, também tem um valor simbólico aqui.

Encruzilhada, romance gráfico publicado em 2011 pela editora Leya Brasil/Barba Negra e reeditado em 2016 por Veneta, tem uma estrutura narrativa parecida com Noite luz. Ele é composto de cinco narrativas gráficas: "Sonhos", “93079482", "Corrente", "Brother", “Encruzilhada"; na última edição de 2016 também inclui "Risco". ${ }^{19}$ Os argumentos dos episódios 

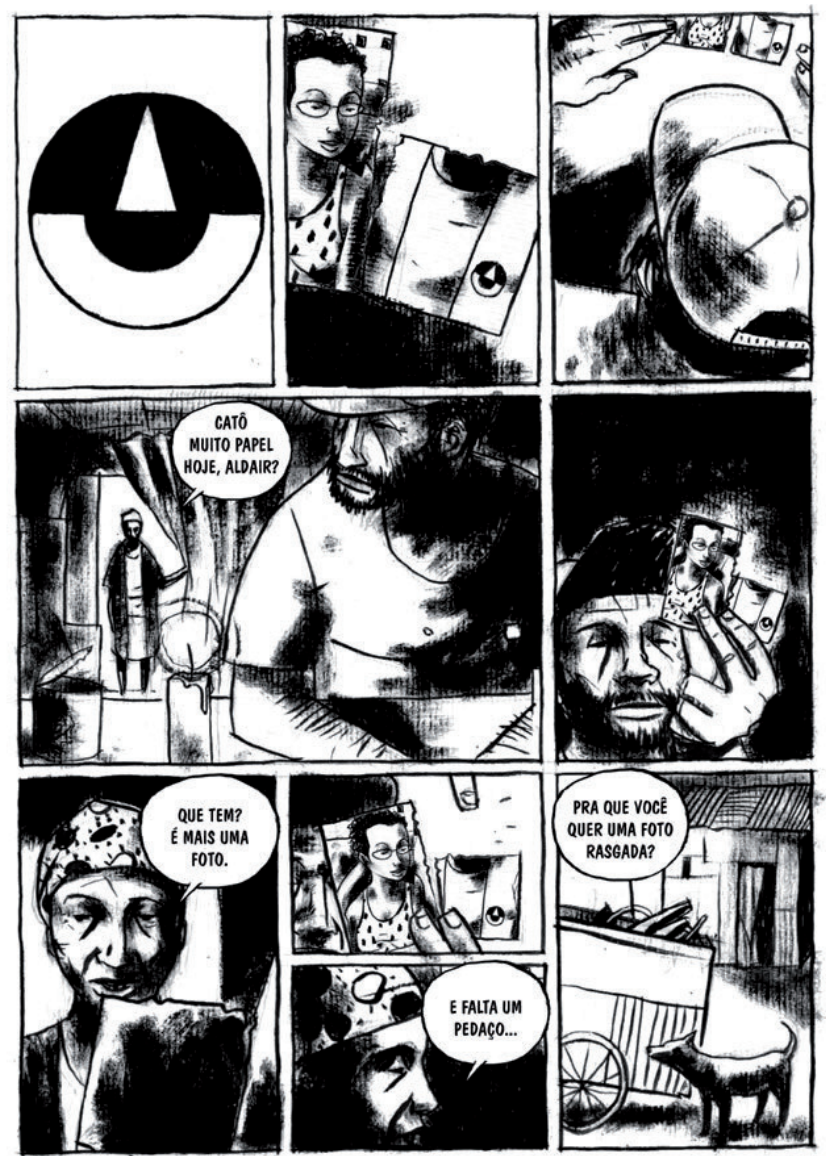

Figura 2. O catador Aldair, de Noite luz. ${ }^{20}$

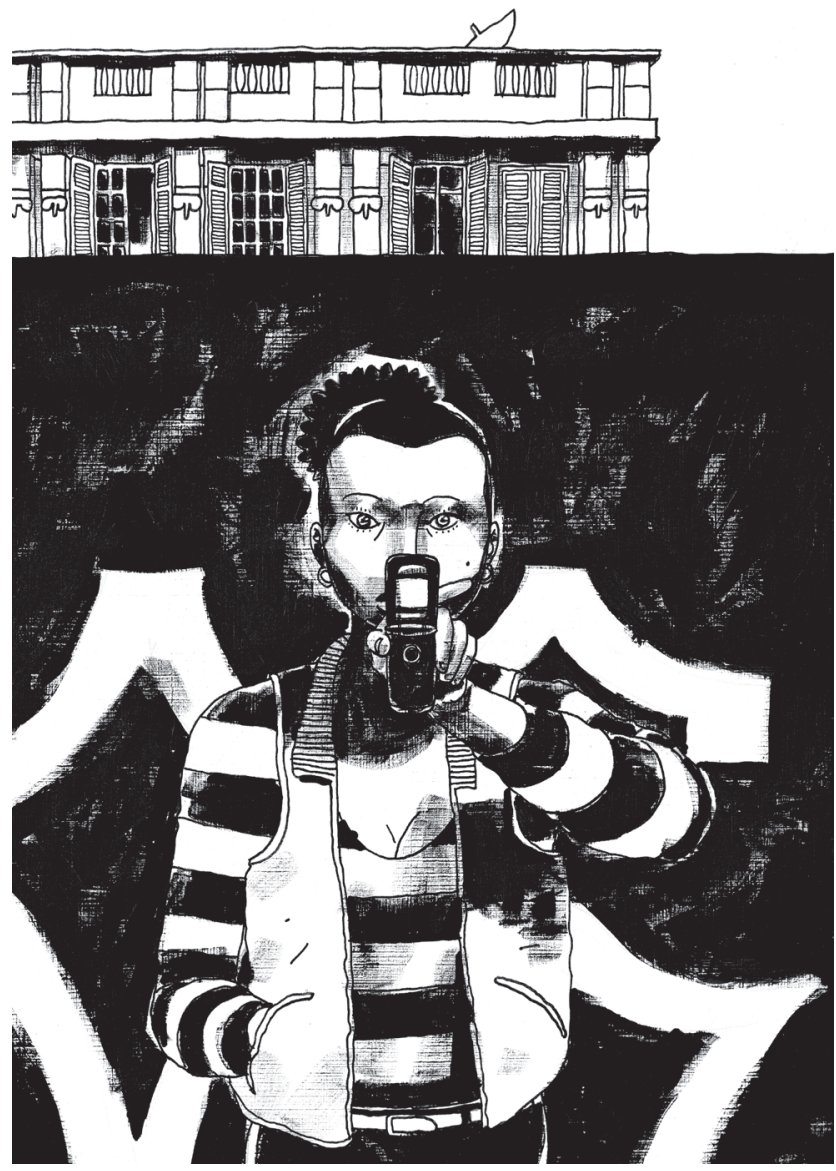

Figura 3. A protagonista Dora, do conto “93079482", de Encruzilhada. ${ }^{21}$

${ }^{20}$ Ver D'SALETE, Noite luz, op. cit., p. 39.

${ }^{21}$ D'SALETE, Marcelo. Encruzilhada, op. cit., p. 158. 
${ }^{22}$ Ver idem, ibidem, p. 10 e 11 , 22,24 e 25.

${ }^{23}$ Ver idem, ibidem, p. 63.

${ }^{24}$ Ver idem, ibidem, p. 17-20, p. 79, 141-144, 147-150.

${ }^{25}$ Ver idem, ibidem, p. 19 e 137.

${ }^{26}$ Ver idem, ibidem, p. 21, 30-48, passim.

${ }^{27}$ YUKA, Marcelo. Disponível em <https://www.dsalete.art. br/hq_encruzilhada.html $>$. Acesso em 18 set. 2018.

${ }^{28}$ MOURA, Pedro. Encruzilhada. Marcelo D'Salete (Barba Negra). Ler BD, 5 set. 2018. Disponível em <http://lerbd. blogspot.com/2011/09/encruzilhada-marcelo-dsalete-barba. html>. Acesso em 18 set. 2018.

${ }^{29}$ No conto "Noite luz", o autor ainda apresenta os diálogos em legendas brancas ao invés de balões. narrados não se encontram diretamente relacionados, mas "93079482" cumpre uma função quase de moldura visual (graphic frame) em relação aos demais contos, visto que momentos da sua narrativa encontram-se intercalados no começo do livro, antes do começo de cada conto particular e no final da obra, norteando a leitura da obra como um todo. Na última página de Encruzilhada, Dora, a protagonista de “93079482”, é representada olhando diretamente para o leitor, onde vemos a tela do seu celular com uma foto do namorado, Beto, assassinado no conto, lembrando-nos da nossa responsabilidade numa sociedade socialmente conflitiva e marcada pela desigualdade.

Além disso, os contos dialogam entre si a partir de experiências similares vivenciadas pelos protagonistas. Como em Noite luz, as narrações compartilham o mesmo cenário, São Paulo, caracterizado por seus prédios altos e emparelhados um do lado do outro, repletos de pichações e que provocam uma sensação de aperto e claustrofobia.

Por meio de perspectivas high e low angle também trabalhadas em Noite luz, um labirinto urbano ameaçador é criado de forma a fazer com que os protagonistas pareçam pequenos e vulneráveis, como no conto "Sonhos", onde os protagonistas Bia e Lino moram num arranha-céu inacabado ${ }^{22}$, ou como em "Corrente", onde a única visão de "liberdade" é mostrada num pátio apertado através de uma perspectiva low angle que mostra um pedaço de céu. ${ }^{23}$ Os diferentes ângulos também são usados para ilustrar os conflitos e as hierarquias entre os personagens marginalizados e seus opressores, representados, muitas vezes, olhando do alto para suas vítimas, como em "Sonhos", "Brother", "Encruzilhada" e "Risco". ${ }^{24}$ A desigualdade social e a violência institucionalizada também são destacadas a partir da representação dos pés dos protagonistas, num contraste entre os pés descalços ou com chinelo dos protagonistas e as botas fortes dos seguranças, como em "Sonhos", ou sapatilhas de última moda, como em "Risco". ${ }^{25}$ Em geral, logomarcas estão onipresentes em Encruzilhada, representando o mundo do consumo como contraponto das condições de vida reais dos moradores da periferia urbana de São Paulo. Assim, em "Sonhos", a pequena Bia usa uma camisa desgastada da Nike enquanto em “93079482" o símbolo da Motorola e painéis de publicidade da Coca-Cola se encontram presentes a todo momento. ${ }^{26}$

Como em Noite luz, o desenho sombrio em preto e branco - o "traço [...] sujo e poético", nas palavras de Marcelo Yuka ${ }^{27}$ - cria uma atmosfera escura e pesada que sublinha um tom de ameaça permanente sobre os protagonistas. D'Salete usa exclusivamente tinta nanquim e acrílico para suas ilustrações em preto e branco, mas, como observa o pesquisador português Pedro Moura em sua resenha do livro, o autor não cumpre simplesmente com a tradição chiaroscura, criando efeitos de alto contraste, senão dá um protagonismo às sombras, dotando-as de uma "organicidade activa [...] que un[e] estas histórias". ${ }^{28}$ As vinhetas são definidas claramente e emolduradas por finas e regulares linhas pretas, tal como em Noite luz. De vez em quando, um balão transgride as linhas da borda de um quadrinho. $\mathrm{O}$ tamanho das vinhetas varia, dependendo do que é representado em cada caso, e se transforma num instrumento para criar ênfase, velocidade ou lentidão. Uma narração externa não existe e só "ouvimos" as vozes dos protagonistas em forma de balões de diálogo. Em comparação com Noite $l u z^{29}$, na qual D'Salete já trabalhara com pouco texto e diálogo e deixa as imagens e expressões de suas figuras conduzirem a narrativa, o que se ob- 
serva é que tal tendência se intensifica ainda mais em Encruzilhada. Quando uma figura é ausente na vinheta e só lemos o que ela diz ou pensa, o texto é apresentado em legendas.

Também aqui os títulos dos contos representam o leitmotiv de cada narrativa. Em "Sonhos", por exemplo, o título pode ser atribuído tanto ao protagonista Lino quanto à sua irmã/amiga Lina e ao segurança Mike. Numa das cenas, Lino olha para um circo que mais parece um pequeno microcosmo irreal no meio dos prédios altos da metrópole. Mas Lino encontra-se excluído deste mundo de sonhos e magia, fato representado pelas grades que o impedem de se aproximar mais e que ainda remetem visualmente às grades de uma cela de prisão. ${ }^{30}$ Quando Lino é ameaçado e atacado por seguranças, a cena é interrompida por um avião que atrai a atenção do líder dos homens, Mike, que então se lembra do aniversário do seu filho - pensa em um avião de brinquedo como presente - e deixa Lino em paz. Essa mesma cena do avião é conectada com Bia que, adormecida, sonha com um avião que leva Lino para longe dela. Nesse caso, trata-se de um pesadelo que, novamente, é conectado com a visão do circo do começo da história, fechando um círculo de sonhos não cumpridos. ${ }^{31}$ Outro conto que brinca com o sentido ambíguo do título é "Corrente", que se refere, inicialmente, ao ritual praticado pelos moradores de passar uma pequena figurinha de vizinho a vizinho sem "quebrar a corrente". ${ }^{32}$ Por outro lado, a palavra pode ser associada também ao destino do protagonista do conto, que parece não mudar nunca. Por último, num sentido mais explícito, poderia se referir também à "corrente de ar" entre as duas janelas abertas do protagonista e da prostituta observadas no começo e no final do conto. Esse jogo de sentidos também é aplicado no conto "Risco", onde o substantivo refere-se, por um lado, a um risco que uma das figuras, líder de um grupo de jovens brancos que sai de uma festa, descobre no carro que deixara sob os cuidados do protagonista Doca. Ao mesmo tempo, o título faz referência ao risco de vida que corre Doca após a descoberta do "risco" no carro, quando é espancado tanto pelo grupo de jovens como pela polícia e se salva da execução por um dos policiais por mera coincidência: uma jornalista está observando a cena desde a sua janela e está tirando fotos da situação, o que intimida os policiais. ${ }^{33}$ Além disso, pode-se relacionar o substantivo, num nível metatextual/visual, ao traço desenhado dos contos gráficos.

Como em Noite luz, existem diferentes jogos de identidade, máscaras e confusões em Encruzilhada. Mike, o segurança de "Sonhos" que ameaça e maltrata o protagonista Lino, é representado com óculos escuros que refletem tudo o que ele vê e, ao mesmo tempo, impedem que saibam como seus sentimentos se expressam através do olhar. Depois do episódio com o avião, quando se lembra do aniversário do filho, Mike tira os óculos e toda a superioridade e frieza do personagem desaparecem com eles; ao final, o que temos é um pai triste e frustrado que só pode comprar um pequeno avião de brinquedo para o filho. ${ }^{34} \mathrm{Em}$ "Encruzilhada", onde se cruzam e entrecruzam dois fios de enredo, somos testemunhas de uma confusão baseada em estereótipos racistas: um dos protagonistas, Janu, afro-brasileiro, é confundido com um ladrão de carros - que, de fato, é um homem branco - pelos seguranças de um grande supermercado e é ameaçado e brutalmente torturado por eles.

Em Noite luz e Encruzilhada, Marcelo D'Salete consegue mostrar os lados sombrios da periferia urbana, com seus perigos, ameaças e injustiças vivenciados por seus protagonistas, vítimas de diferentes agentes de

\footnotetext{
${ }^{30}$ Ver D'SALETE, Marcelo. Encruzilhada, op. cit., p. 16.

${ }^{31}$ Ver idem, ibidem, p. 20-22; p. 25.

${ }^{32}$ Idem, ibidem, p. 56

${ }^{33}$ Ver idem, ibidem, p. 150.

${ }^{34}$ Ver idem, ibidem, p. 26 e 27.
} 
${ }^{35}$ D'SALETE, Marcelo. Angola Janga, op. cit., p. 419.

36 "The scars caused by slavery are still poorly understood and discussed [...]. Brazil is an extremely unequal, racist country, and this is closely related to its past. We can't continue to consider slavery as something soft in our history. [...] More than quantitive data, my intention was to speak from the perspective of enslaved Africans in the period and address the modes of resistance of these people. From the most individual way to the forms of collective struggle. There are few such stories in comic format that tried to address this in a very personal way. [...] We need fiction to try to overcome these limits and create new reading possibilities". D'SALETE, Marcelo apud FRANK, Priscilla. Striking graphic novel tells the story of brazilian slavery through the eyes of the oppressed. 4 jul. 2015. Disponível em <https://www.huffingtonpost.com/2015/04/07/ marcelo-dsalete-brazilian-slavery_n_7011238.html?guccounter $=1>$. Acesso em 19 set. 2018. Agradeço a Ivan Lima Gomes pela tradução. violência: narcotraficantes, acossadores, seguranças e policiais. Ao mesmo tempo, o autor não mostra simplesmente um mundo em "preto e bran$\mathrm{co}^{\prime \prime}$, senão antes em gradações complexas: alguns dos seus protagonistas tentam se opor às violências sofridas, como Doca em "Risco"; por outro lado, alguns dos agressores também revelam sua vulnerabilidade, como o segurança Mike no conto "Sonhos".

\section{História(s) redesenhada(s): Palmares e a resistência negra em Cumbe e Angola Janga}

Os romances gráficos Cumbe (2014) e Angola Janga (2017) são o resultado de uma pesquisa de mais de dez anos de D'Salete. No epílogo que acompanha a obra mais recente, o artista conta o seu primeiro contato com a História de Palmares e explica como se cristalizou a ideia para o projeto:

A história do Quilombo de Palmares [...] chegou até meus ouvidos nos primeiros anos escolares. Uma colega disse, categórica: hoje é dia 20 de novembro, dia de Zumbi dos Palmares! Olhei curioso. Mal conhecia a história de Zumbi ou qualquer outro fato da história negra no Brasil. Esse universo foi descortinar-se somente anos mais tarde, por influência do rap, da literatura e de filmes. Muito tempo depois, já na universidade, tive contato com textos sobre o antigo conflito da Serra da Barriga. Naquele momento, percebi que Palmares foi um grande acontecimento. Um dos principais conflitos do século XVII e do Brasil colonial. Mais do que isso, o maior levante escravo negro na América, comparável à Revolução Haitiana. Ainda vacilante, iniciei um primeiro roteiro sobre Palmares. Tracei ali quais seriam os principais fatos e a linha central da narrativa. Esbocei alguns desenhos, mas não possuía as informações necessárias para dar cabo do projeto naquele momento. Passei os anos seguintes estudando textos e a iconografia do período. ${ }^{35}$

No contexto da desigualdade e dos conflitos atuais no país, o autor interpreta o passado mal digerido como raiz dos dilemas vividos pelo Brasil ainda hoje:

As cicatrizes causadas pela escravidão seguem, ainda, muito pouco compreendidas e discutidas [...]. O Brasil é um país extremamente desigual e racista, o que se relaciona diretamente com este passado. Nós não podemos continuar considerando a escravidão como algo leve em nossa história [...]. Mais do que dos quantitativos, minha intenção foi falar desde a perspectiva dos africanos escravizados nesta época [da colonização], e indicar os modos de resistência de tais povos - desde os mais individualizados às formas de luta coletiva. Há poucas histórias em formato $\mathrm{HQ}$ que tentaram lidar com este tema de forma tão pessoal [...]. Precisamos de ficção para tentar superar estes limites e criar novas possibilidades de leitura. ${ }^{36}$

De fato, Cumbe e Angola Janga não são meras narrativas visuais dos fatos históricos conhecidos sobre os mocambos. Trata-se antes de uma re-imaginação dos acontecimentos nos arredores de Palmares desde a perspectiva dos oprimidos, representados, porém, não como vítimas, mas como agentes de sua própria resistência. A pesquisa de D'Salete baseia-se tanto em crônicas do tempo colonial como em registros policiais daquela época, além de literatura acadêmica mais recente. Os respectivos contos e episódios em Cumbe e Angola Janga muitas vezes se inspiram nessas fontes, abordadas por D'Salete desde o campo ficcional das HQs. O autor também 
visitou Maceió durante os anos de pesquisa para obter imagens da paisagem e dos lugares que iam formar o palco para seus livros. O resultado é uma narrativa gráfica complexa em relação à representação visual, ao desenvolvimento dos personagens e à estrutura narrativa.

Cumbe, recentemente reeditada pela editora Veneta em 2018, consiste em quatro contos gráficos autônomos. Como no caso das duas outras obras de D'Salete discutidas mais acima, os contos relacionam-se tematicamente: 1) "Calunga", palavra proveniente do bantu significa, de acordo com o glossário que acompanha a obra, "boneco pequeno, camundongo, figuras humanas em desenhos infantis, as bonecas dos cortejos do maracatu, céu, morte, o próprio homem negro e muitos outros sentidos. 'O termo multilinguístico banto kalunga encerra ideia de grandeza, imensidão, designando Deus, o mar, a morte'". ${ }^{37}$ 2) "Sumidouro"; 3) o conto "Cumbe" se vale de uma palavra que provém das línguas de Angola e do Kongo e que é usada como sinônimo de quilombo; 4) "Malungo" 38 , outra palavra banto, utilizada com o significado de companheiro. Cada capítulo conta uma espécie de capa, que introduz elementos fundamentais do conto correspondente ao lado do título.

Estilisticamente, Cumbe é parecida com Noite luz e Encruzilhada, ainda que o cenário seja completamente diferente: paisagens abertas, matagais, plantações de cana de açúcar, fazendas e engenhos. Também aqui D'Salete usa perspectivas low e high angle para ilustrar a desigualdade de poderes nas suas histórias. Tal como nos trabalhos anteriores, há um contraste entre os pés descalços dos escravos com os pés dos fazendeiros e suas botas pesadas. Com sua linguagem gráfica de orientação fílmica e poética, ele usa e instrumentaliza uma gama completa de long shots e close-ups para narrar os acontecimentos, movimentando-se entre meras insinuações que incitam a interpretação do leitor e ilustrações explícitas que arrebatam o leitor com sua veemência. Como nas obras anteriores, uma narração externa não existe e o discurso direto é limitado a um mínimo, enquanto a obra focaliza expressões faciais e a linguagem corporal dos personagens. Estes são acompanhados ao longo dos contos por elementos da cultura e mitologia bantu: desenhos - vide o símbolo quioco ${ }^{39} \mathrm{em} \mathrm{"calunga"} \mathrm{ou} \mathrm{a}$ tartaruga cabinda em "cumbe" -, plantas medicinais como a nsanga ("calunga"), um vissungo (um canto) em "sumidouro" ou a pequena escultura de Chibidinda Ilunga, um mítico rei-herói africano, em "cumbe".

Todos esses elementos atuam como símbolos de identificação e de força e esperança pela liberdade, ainda que eles também possam servir para gerar pavor como é o caso do quibungo que aparece no conto "Malungo". Os irmãos protagonistas, Damião e Ciça, escutam histórias de uma escrava sobre o quibungo, uma mistura entre bicho selvagem e ser humano que tem seu focinho com dentes na nuca, para onde joga suas presas. Pouco depois, a pequena Ciça tem um encontro com a besta que, ao final, revela-se como o fazendeiro violento e igualmente monstruoso que estupra e mata uma criança.

Esse episódio é, com certeza, um dos mais pesados do livro, o que não diminui em nada a carga poética e lírica do conto "Malungo". Depois da morte de sua irmã menor, Damião foge da plantação e, anos depois, retorna acompanhado de vários "malungos" do mocambo para incendiar a fazenda. Ele leva os restos mortais de Ciça para um lugar pacífico, dentro do mocambo, onde ela pode estar livre. Essa cena é seguida por uma representação close-up do focinho do quibungo; pouco a pouco, vinheta

${ }^{37}$ D'SALETE, Marcelo. Cumbe, op. cit., p. 171.

${ }^{38}$ Idem, ibidem, p. 172. Para uma análise detalhada dos contos gráficos de Cumbe, ver WROBEL, Jasmin, op. cit.

${ }^{39}$ Quioco refere-se aos povos tchokwes, uma etnia bantu. 
${ }^{40}$ D'SALETE, Marcelo. Cumbe, op. cit., p. 146.

${ }^{41}$ Ver idem, ibidem, p. 32.
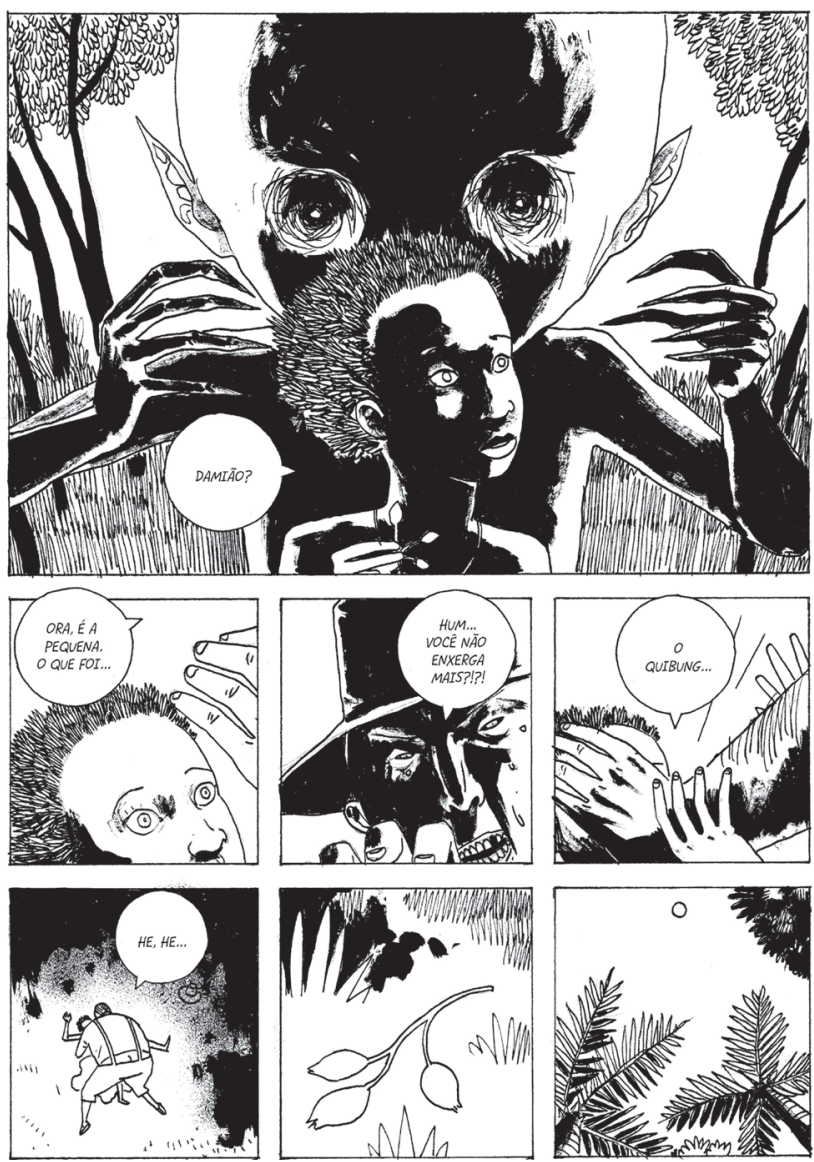

Figura 4. Ciça Cumbe. Ciça encontra o quibungo. Cena do conto "Malungo", de Cumbe. ${ }^{40}$
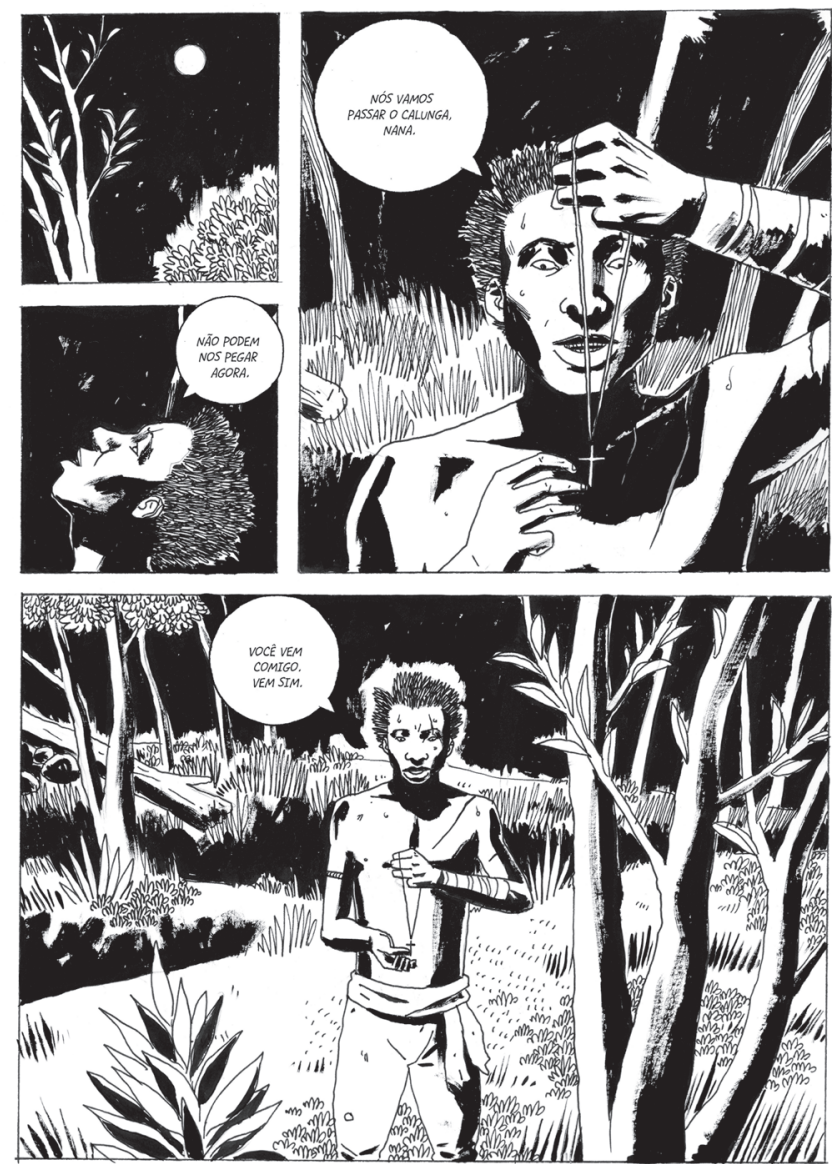

Figura 5. Valu Cumbe. Valu com o colar de Nana, do conto "Calunga", de Cumbe. ${ }^{41}$ 
por vinheta, a perspectiva do observador é distanciada cada vez mais, até que vemos o quibungo sentado numa flor branca, pequeno e inofensivo. As últimas vinhetas mostram Ciça cheirando esta flor e o quibungo, minúsculo, já não mais representa um perigo para ela. Assim como a for, o seu vestido e o cenário de fundo são brancos, trazendo-nos uma sensação de paz e sossego. ${ }^{42}$

Uma revolta de escravos também é tematizada em "Cumbe" e, se bem a revolta é abatida graças às armas superiores dos portugueses, a esperança e a crença como caminhos à liberdade são mantidas pela figura da velha sábia, a única sobrevivente: "Cumbe virá novamente. Cumbe é força... ele sempre retorna". ${ }^{43}$ Os outros dois contos, "Calunga" e "Sumidouro", mostram histórias individuais de resistência que terminam em tragédia. Valu, protagonista de "calunga", quer enfrentar o calunga, "o mar que não acaba", para fugir do engenho onde trabalha com sua parceira Nana, uma escrava doméstica. Nana, que não é vítima da violência brutal que Valu encara no campo de cana de açúcar, prefere ficar na fazenda; a escravidão dela também é espiritual, o que se manifesta na cruz que ela usa no seu colar. Para poder levar Nana com ele, Valu, desesperado, mata a parceira e pega seu colar como símbolo de sua presença.

Caçado por um homem da fazenda e seu cachorro bravo, Valu consegue chegar ao mar, onde afunda. A cena é onírica e muito poética: nas profundidades da água escura, quem espera por ele é Nana e, no mar, os lábios dos dois protagonistas se encontram mais uma vez. O conto termina, porém, com a visão de Nana no mundo real, esfaqueada e sem vida. A história dos dois protagonistas é refletida pelo ideograma quioco com que a trama é introduzida e que reaparece como leitmotiv nos encontros de Valu e Nana e ao final do conto, desta vez riscado. Segundo José Redinha, “este símbolo quioco representa um ninho e dois pássaros [que $t$ ] rançam os sentidos de espera resguardada e de liberdade mundo afora".${ }^{44} \mathrm{O}$ conto "Sumidouro" será comentado mais adiante, pela forte proeminência dos debates em torno da representação feminina neste conto, tema da próxima seção.

No caso de Angola Janga, D'Salete conta, pela primeira vez, uma trama única, dividida em onze capítulos e mantendo a tendência de narrar uma história em vários episódios e sob diferentes ângulos de perspectiva. A extensão da obra, de 432 páginas, o tema histórico e a linguagem visual poética adotada permitem-nos pensá-la não tanto como um romance gráfico, senão antes como uma verdadeira epopeia gráfica que abarca o intervalo entre 1655, ano de nascimento de Zumbi dos Palmares, e 1702, sete anos após a morte de Zumbi quando, na ficção, a guerreira Andala volta ao engenho para continuar a luta. A trama é inspirada na história do líder da resistência negra e do Quilombo dos Palmares mas, como em Cumbe, D'Salete usa a ficção para re-imaginar os vazios da historiografia. O título da obra já indica o lugar de enunciação desde o qual a história de Palmares é contada: "Angola Janga", "Pequena Angola”, foi o nome que os próprios quilombolas deram ao Quilombo dos Palmares. Enquanto Cumbe já contava com recursos paratextuais como um glossário e uma espécie de posfácio de autoria do "escritor, angoleiro e pedagogo" Allan da Rosa, Angola Janga vem acompanhada de um texto sobre os mocambos e engenhos no século XVII, pelo epílogo "Picadas e sonhos", por uma cronologia da Guerra de Palmares, vários mapas que ilustram o desenvolvimento dos quilombos no Brasil e um glossário. Além disso, cada capítulo é introduzido com uma

${ }^{42}$ Idem, ibidem, p. 158-163.

${ }^{43}$ Idem, ibidem, p. 130.

${ }^{44}$ REDINHA, José apud D'SALETE, Marcelo. Cumbe, op. cit., p. 171. 
${ }^{45}$ D'SALETE, Marcelo. Angola Janga, op. cit..

${ }^{46}$ Idem, ibidem.

${ }^{47}$ Ver idem, ibidem, p. 91 e 92.

${ }^{48}$ Ver idem, ibidem, p. 340 e 341.

${ }^{49}$ Ver idem, ibidem, p. 380-386.

${ }^{50}$ Ver idem, ibidem, p. 105.

${ }^{51}$ Ver idem, ibidem, p. 323.

${ }^{52}$ Ver idem, ibidem, p. 404. ou várias citações de crônicas de época, que funcionam como um comentário ao episódio gráfico narrado por Marcelo D'Salete. Tais comentários, na maioria dos casos, expressam a visão dos opressores e são retificados pela perspectiva dos oprimidos (re)imaginada pelo autor ao longo da sua narrativa gráfica.

Os acontecimentos narrados em Angola Janga giram em torno das últimas décadas do Quilombo dos Palmares, priorizando o destino e a influência de Zumbi dos Palmares assim como o de muitos atores diferentes que fizeram sua parte na história do mocambo - alguns deles bem documentados pela historiografia, como Ganga-Zumba, Acotirene, António Soares, o bandeirante paulista Domingos Jorge Velho ou o capitão Furtado de Mendonça. Estilisticamente, a obra não se distingue muito de Cumbe, se bem que chama a atenção por, devido à extensão da obra e do tempo narrado, utilizar-se frequentemente de vinhetas menores, às vezes até 12 por página.

Como nas obras anteriores, nota-se grande atenção aos detalhes. A brutalidade de figuras como Domingos Jorge Velho ou Inácio, este último fictício, é contrabalançada por manifestações de amor, amizade e solidariedade entre os quilombolas, e por momentos visualmente muito poéticos, como a morte do próprio Zumbi dos Palmares no penúltimo capítulo, "O abraço". ${ }^{45}$ Como no conto "Malungo", de Cumbe, os "monstros humanos" em Angola Janga também são relacionados a entidades mitológicas; neste caso, Domingos é associado com o Anguêri no capítulo 7, "Selvagens", entidade mitológica guarani que seria uma espécie de morto-vivo da floresta que ataca à noite. ${ }^{46}$

No mesmo capítulo e nos capítulos seguintes, o papel da população indígena nos quilombos e na resistência negra é tematizado. O título do capítulo sugere certa ambiguidade porque, com "selvagens", não se refere às pessoas indígenas, ao contrário do que usual e discriminatoriamente se costuma dizer, senão aos bandeirantes paulistas, com sua postura predatória e violenta perante os indígenas. Mas, como em outros livros de D'Salete, também aqui não é possível diferenciar simplesmente entre "bom" $\mathrm{e}$ "mau". Assim encontram-se figuras como o negro Zona - inspirado em Ganga Zona -, que não hesita em matar um malungo e em mentir para conseguir acordo de paz com os portugueses ${ }^{47}$, ou o português Joaquim, que se junta aos quilombolas e morre lutando ao lado deles. ${ }^{48} \mathrm{~A}$ "traição" de Zumbi pelo mulato Antônio Soares é tematizada com muita empatia, enquanto o conflito interior do personagem é mostrado com riqueza de detalhe. Soares, na ficção de Marcelo D'Salete, morre ao final ainda na resistência e consegue ajudar a sua parceira Andala fugir. ${ }^{49}$

Outro elemento que já teve um papel importante em Cumbe e que reaparece em Angola Janga é a escultura de Chibinda Ilunga, um mítico rei tchokwe. No capítulo de Angola Janga intitulado "Aqualtune", a escultura se encontra ainda na possessão de Ganga Zumba, mas a figura é entregue por Zona ao governador para fechar o acordo de paz. ${ }^{50}$ Mais adiante, em "Doce inferno", a escultura desaparece de repente, motivando um ataque de raiva do governador. Fica claro que este acredita ter certo controle sobre Palmares pela presença da estatueta. Insinua-se que uma das escravas domésticas do governador a pegou..$^{51} \mathrm{~A}$ estátua reaparece ao final do livro, quando Andala volta em 1702, sete anos depois das mortes de Zumbi e Soares, levando a figura de Chibinda Ilunga em seu cinto, como a dizer: a luta continua. ${ }^{52}$ 
Também presentes ao longo da trama estão símbolos das culturas Asante - Ananse Ntontan, "teia de aranha" - e Tchokwe - Sona, um conjunto de símbolos formado por pontos e linhas sinuosas -, que se entrelaçam com a trama e que são, ao mesmo tempo, a manifestação simbólica da narrativa visual. Em uma cena no capítulo 6, "Encontros", Tata explica para a pequena Dara, filha do Zumbi, o funcionamento de uma teia de aranha como proteção e armadilha ao mesmo tempo, o que ele ilustra justamente com o símbolo Ananse Ntontan. ${ }^{53}$ Em geral, é notável a presença e função dos insetos no livro. Muitas vezes são os elementos vinculantes entre uma visão e a realidade; noutras, mostram o "caminho" aos protagonistas, como no caso do mesmo capítulo, quando Dara persegue um escaravelho-rinoceronte no alto de uma árvore. De lá, ela tem uma boa visão do engenho e entende a monstruosidade do lugar. ${ }^{54}$ Por outro lado, é a partir de um escaravelho que o padre tem a ideia de construir uma cerca em diagonal para atacar Palmares, o que finalmente leva ao sucesso dos bandeirantes e à conquista do mocambo. ${ }^{55}$

Como no caso de Cumbe, o livro termina com um final que evoca esperança. Depois das mortes de Zumbi e Soares, tudo parecia perdido. Dara e outras escravas sobreviventes estão presas novamente num engenho, em 1702. A filha de Zumbi foge pelo teto do celeiro onde as mulheres dormem, mas é capturada pelo Sr. Cunha, que pretende castigar a menina. Justo nesse momento chega Andala com alguns quilombolas sobreviventes e liberta as mulheres. As últimas vinhetas mostram Dara com uma lança nos braços, olhando para o céu vasto. Nesse momento, podemos nos lembrar das palavras da velha sábia do conto "cumbe", que já citamos antes: "Cumbe virá novamente. / Cumbe é força... ele sempre retorna". ${ }^{56}$

\section{A visualização de perspectivas femininas na obra de Marcelo D'Salete}

Ao contrário da maioria dos quadrinistas masculinos que, até hoje, dominam o meio das HQs, Marcelo D'Salete não deixa de incorporar também protagonistas mulheres igualmente complexas e lutadoras em seus trabalhos, conforme destacado no caso da já mencionada guerreira Andala em Angola Janga, única figura retratada na contracapa da primeira edição do livro. É importante mencionar que mulheres desempenharam um papel importante na história da resistência negra. Podemos pensar, por exemplo, em Aqualtune, mãe de Ganga Zumba, avó materna de Zumbi e líder de uma força de dez mil homens na batalha de Mbwila, em Angola, 1665. Ela foi trazida prisioneira para Pernambuco, mas conseguiu fugir para Palmares pouco depois de sua chegada, liderando um mocambo que mais tarde receberia seu nome. O capítulo 3, "Aqualtune", se passa no mocambo de mesmo nome, mas, na versão narrada por D'Salete, o mocambo recebe o nome Aqualtune por escolha de Acotirene, outra guerreira-matriarca de Palmares. ${ }^{57}$ Para ilustrar a representação de protagonistas femininas na obra de D'Salete, gostaria de tematizar mais dois exemplos concretos, um de Encruzilhada, outro de Cumbe.

No conto "Brother", de Encruzilhada, as protagonistas são duas irmãs que vendem DVDs pirateados em São Paulo. Num dado momento, a mais nova, Jô, fica sozinha com a mercadoria enquanto sua irmã vai buscar troco. A trama de ambas é entrelaçada com a de Juninho e um amigo que vivem por perto e que passam pela tenda de Jô. Juninho tenta distrair a menina

\footnotetext{
${ }^{53}$ Ver idem, ibidem, p. 204.

${ }^{54}$ Ver idem, ibidem, p. 212.

${ }^{55}$ Ver idem, ibidem, p. 300

${ }^{56}$ D'SALETE, Marcelo. Cumbe, op. cit., p. 130.

${ }^{57}$ Ver D'SALETE, Marcelo. Angola Janga, op. cit., p. 96.
} 
${ }^{58}$ Ver idem, Encruzilhada, op. cit.

${ }^{59}$ Ver NAVARRETE, Juan. La negritud em la historieta brasileña: um primer acercamiento a la novela gráfica Cumbe y la obra de Marcelo D'Salete. Pacarina del Sur, v. 6, n. 23, abr.-jun. 2015, México D.F. Disponível em <http://pacarinadelsur.com/ home/senas-y-resenas/1149-lanegritud-en-la-historieta-brasilena-un-primer-acercamiento-a-la-novela-grafica-cumbe-y-la-obra-de-marcelo-d-salete>. Acesso em 25 de set. 2018.

${ }^{60}$ D'SALETE, Marcelo. Cumbe, op. cit., p. 52.

${ }^{61}$ Idem, ibidem, p. 79.

62 "É um canto de trabalho em versos metafóricos, segundo o Dicionário da escravidão de Clóvis Moura. Muito usado pelos negros de Minas Gerais para se comunicarem sem serem compreendidos pelos brancos. $\mathrm{O}$ verso 'Ei oia lá / ô minino Mané no uandá...' foi coletado por Aires Machado Filho e era cantado para embalar crianças nos braços". D'SALETE, Marcelo. Cumbe, op. cit., p. 173.

${ }^{63}$ Ver idem, ibidem, p. 76-85. insinuando que "o rapa" está vindo, palavra com que se refere a uma ação policial contra moradores da rua e vendedores de rua. Quando Jô, nervosa, se vira, Juninho furta o DVD do filme japonês Brother, de Takeshi Kitano (2000), sobre a máfia Yakuza. A pequena Jô percebe que foi enganada e reclama, corajosamente, o DVD, mas Juninho a empurra no chão. Ela está sozinha e chora, mas num flashback poético, recorda-se da importância de ganhar dinheiro para poder visitar a mãe. Depois da visão, ela levanta com novo ânimo e persegue Juninho e seu amigo. Jô reencontra-os num cassino e consegue pegar o DVD quando o amigo de Junino se distrai com um videogame. Orgulhosa, ela volta à tenda e encontra sua irmã, que perdeu todo o ocorrido. À primeira vista, o título do conto poderia fazer referência à ausência de uma figura protetora, como um irmão maior, mas, com sua determinação de resistir à injustiça vivenciada, Jô prova que não tem necessidade do "Brother". 58

O outro conto que gostaria de comentar é "Sumidouro", de Cumbe. O título refere-se à prática então comum de arremessar escravos "rebeldes" nos poços profundos das fazendas. ${ }^{59}$ Ele narra a história de uma relação complexa entre uma mulher escravizada, Calu, e seu "dono", o senhor Tomé. A primeira vinheta mostra um close-up de um crânio de boi, símbolo da morte. Nas vinhetas seguintes, distanciamo-nos pouco a pouco e o ângulo cada vez maior revela primeiro o rosto do senhor Tomé abaixo do crânio de boi; em seguida, seu corpo completo e o bar onde ele está; e, finalmente, tem-se uma visão do bar visto do alto. A introdução desta figura, cujo olhar direciona-se diretamente ao leitor, antecipa o final trágico de "Sumidouro": "Calu não podia ter feito isso. Não podia... Agora será diferente" ${ }^{60}$

Calu, "sua" escrava doméstica, aparece na próxima cena, ao lado do sumidouro, o leitmotiv desse conto, aparentemente falando com alguém. Os flashbacks, contados desde a perspectiva da protagonista Calu, revelam o que aconteceu: estuprada por seu "dono", ela engravidara. A esposa ciumenta do senhor Tomé aproveita-se de um momento de distração de Calu para pegar o bebê e jogá-lo no sumidouro, ato que é só insinuado na narrativa. Em desespero e sem ter nenhuma pessoa por perto que pudesse ajudá-la, Calu relata o ocorrido para o padre Antônio, o que deixa Tomé enfurecido. Ele leva Calu de volta para o engenho. Quando, algumas horas e bebidas mais tarde, planeja castigá-la com o chicote, Tomé a encontra do lado do sumidouro da fazenda, alucinada. No momento em que pretende dar a primeira chicotada nela, Calu abre seus olhos, aproxima-se e o beija. Num primeiro momento, ele parece emocionado com esse gesto, mas pouco depois começa a estrangulá-la, até que Calu não se move mais. Como escrava, ela deve ficar passiva e suportar a violência sexual; na visão de Tomé, ela não deve dar o primeiro passo: “Não podia ser assim. / Não desse jeito" ${ }^{61}$ Quando recupera a consciência, ela pega a faca da cozinha que se encontrava escondida em seu avental. Mostram-se close-ups dos rostos dos protagonistas, acentuando a intensidade emocional da situação, quando Calu degola o pai do seu filho que é, também, o seu estuprador. As lágrimas de Calu transformam-se numa visão ou num espectro do seu bebê. Entoando o vissungo ${ }^{62}$ que ela sempre cantava para o filho, o bebê espectro se levanta no ar e transforma-se em uma das estrelas, vivo, para sempre, na eternidade. ${ }^{63}$ A resistência de Calu através da morte de seu agressor é só uma das manifestações do levantamento de vozes femininas na obra de D'Salete. 

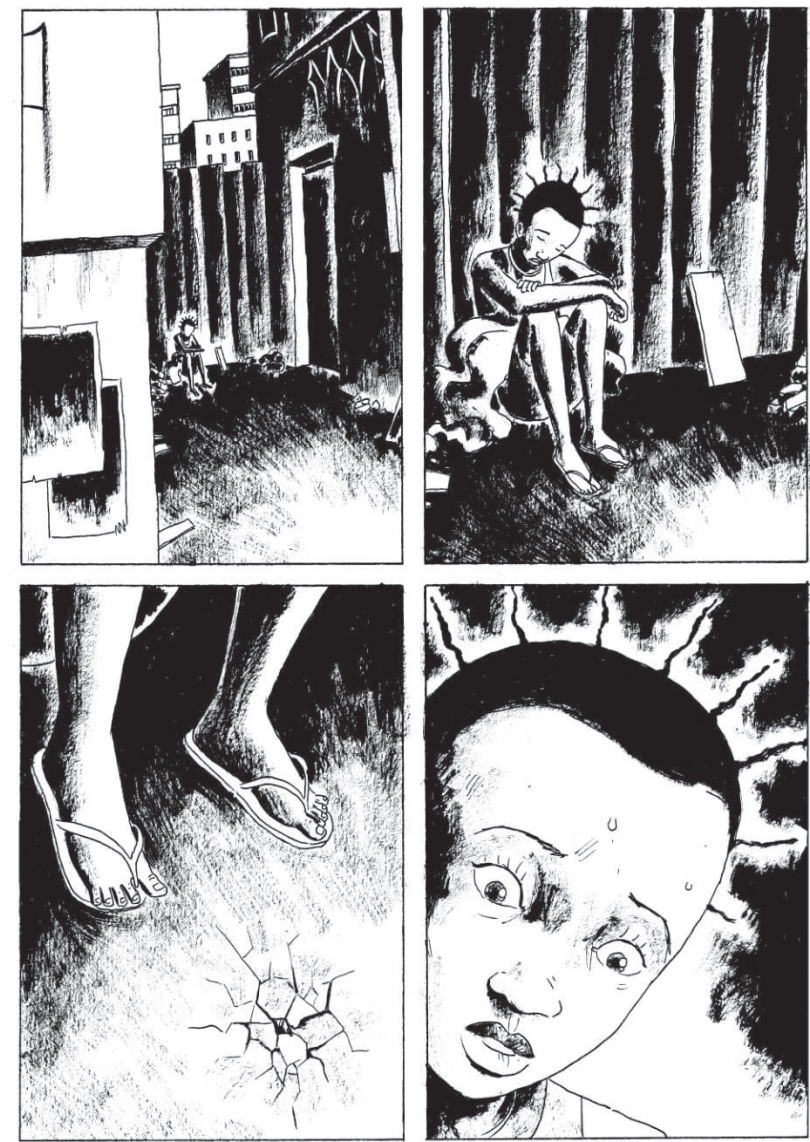

Figura 6. Dara Angola Janga. Dara, nas ruas de São Paulo. ${ }^{64}$
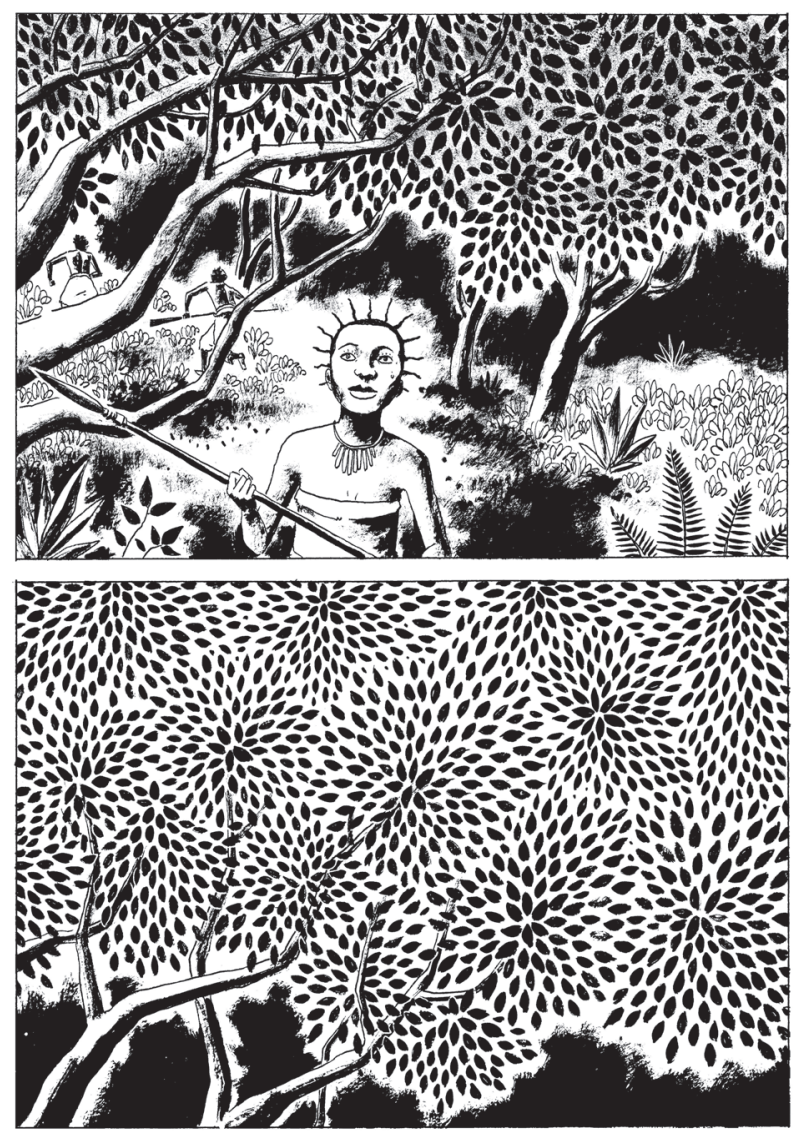

Figura 7. Dara Angola Janga. Dara, a luta continua. ${ }^{65}$

${ }^{64}$ D'SALETE, Marcelo. Angola Janga, op. cit., p. 392

${ }^{65}$ Idem, ibidem, p. 408. 
Para terminar, gostaria de lembrar o começo do último capítulo de Angola Janga. "Passos na noite" começa com um enquadramento amplo, que parte do universo e que, aos poucos, aproxima-se da Terra. Aumentando o zoom mais e mais, o autor nos leva a um cenário contemporâneo, dentro de uma cidade grande que, de novo, pode ser São Paulo. Chegamos, finalmente, a uma pequena rua lateral escura, onde uma menina está sentada sozinha. Pela aparência física, podemos identificá-la como Dara, a filha de Zumbi. De repente, a terra debaixo dela começa a quebrar e se abre um abismo, que engole a menina.

Ela cai num mundo escuro e onírico, numa estrutura de rodas dentadas que se movem e tiram dela algo que remete ao suco da cana de açúcar. Marcelo D'Salete relaciona aqui diretamente a história de escravidão com o destino de jovens afro-brasileiros hoje em dia. E é significativo que se utilize da figura de Dara, filha de Zumbi, para visualizar tal relação, especialmente porque a pequena Dara também é a figura que encerra Angola Janga: libertada por Andala, outra mulher forte na ficção do quadrinista paulistano, Andala, nas últimas vinhetas Dara levanta seu olhar ao céu, com o rosto cheio de esperança e mantendo a lança nos seus braços.

Artigo recebido em 29 de junho de 2019. Aprovado em 31 de agosto de 2019. 